\title{
REVIEW
}

\section{Patient satisfaction in emergency medicine}

\author{
C Taylor, J R Benger
}

Emerg Med J 2004;21:528-532. doi: 10.1136/emj.2002.003723

A systematic review was undertaken to identify published evidence relating to patient satisfaction in emergency medicine. Reviewed papers were divided into those that identified the factors influencing overall satisfaction in emergency department patients, and those in which a specific intervention was evaluated. Patient age and race influenced satisfaction in some, but not all, studies. Triage category was strongly correlated with satisfaction, but this also relates to waiting time. The three most frequently identified service factors were: interpersonal skills/staff attitudes; provision of information/explanation; perceived waiting times. Seven controlled intervention studies were found. These suggested that increased information on ED arrival, and training courses designed to improve staff attitudes and communication, are capable of improving patient satisfaction. None of the intervention studies looked specifically at the effect of reducing the perceived waiting time. Key interventions to improve patient satisfaction will be those that develop the interpersonal and attitudinal skills of staff, increase the information provided, and reduce the perceived waiting time. Future research should use a mixture of quantitative and qualitative methods to evaluate specific interventions.

See end of article for authors' affiliations

Correspondence to: Dr J Benger, Academic Department of Emergency Care, Emergency Department, Bristol Royal Infirmary, Bristol BS2 8HW, UK; Jonathan.Benger@ ubht.swest.nhs.uk

Accepted for publication 7 March 2003
O ver the past 10 years there has been increasing interest in "consumer satisfaction" in the NHS, starting with the Patients' Charter of 1991, and culminating with the NHS Plan. ${ }^{1}$

The essence of the NHS Plan is to make patients' views and interests the driving force behind reform. Among the core principles of the plan is the statement that "quality will not just be restricted to clinical aspects of care, but include ... the entire patient experience" ${ }^{\prime \prime}$ To show that the service is responding to patient priorities, every NHS organisation is now required to publish an annual account of the views received from patients, and the action taken as a result. ${ }^{2}$

Few clinicians would disagree with the idea that improving patient satisfaction is a desirable end in itself. Related benefits may include improved morale and job satisfaction in emergency department (ED) staff, a reduced tendency for patients to seek further opinions, and a reduced incidence of complaints and litigation. There is also evidence of improved patient compliance. $^{34}$ Improved satisfaction in EDs is likely to have a significant impact on the public view of hospital and emergency care in general.

The aim of this systematic review was to identify the published evidence relating to patient satisfaction in emergency medicine, thereby providing useful information for clinicians, and helping to guide future strategies for assessment and improvement in this area.

\section{METHODS}

A literature search was carried out using the WebSPIRS from SilverPlatter interface, accessed via the SWICE gateway. The Medline, CINAHL, EMBASE, ASSIA, and HMIC databases were searched from January 1990 to January 2002, using the terms [PATIENT-SATISFACTION and ("Emergency Department" or "Accident and Emergency" or "Casualty" (TW))].

Papers of potential relevance were retrieved, and their reference lists searched for additional relevant material. This process was repeated until no new information was found.

Reviewed papers were grouped under two headings:

(1) Research to identify and rank factors influencing overall satisfaction in ED patients.

(2) Intervention studies attempting to improve patient satisfaction in the ED.

\section{RESULTS}

The initial computerised database search identified 583 papers of potential relevance. Many papers were found that included measures of patient satisfaction "tagged on" to a clinical intervention study, but these tended to show the acceptability of the intervention, rather than its effect on satisfaction. Such studies were therefore excluded.

The studies reviewed were too heterogeneous for formal meta-analysis. Nevertheless, the following key points emerged:

\section{Choosing factors to assess}

Most papers assessed a variety of service factors, process of care measures, or patient related factors chosen from the literature, staff opinions, or ad hoc by the authors.

The most frequently assessed service factors in emergency medicine were: perceived and actual waiting times; explanations/information on multiple aspects of process and treatment; staff attitudes; ED environment; perceived standards of technical care. Table 1 lists the factors assessed in individual studies, the assessments used, and a summary of the main findings. 
Table 1 Summary of factor and global satisfaction assessment studies

\begin{tabular}{|c|c|c|c|c|}
\hline $\begin{array}{l}\text { Author, year, } \\
\text { and country }\end{array}$ & Factors assessed & $\begin{array}{l}\text { Method of assessing } \\
\text { factor satisfaction }\end{array}$ & $\begin{array}{l}\text { Method of assessing } \\
\text { global satisfaction }\end{array}$ & Main findings \\
\hline $\begin{array}{l}\text { Biorvell and Steig }{ }^{15} \\
1991 \text { Sweden }\end{array}$ & $\begin{array}{l}\text { Perceived levels of } \\
\text { information on arrival }\end{array}$ & $\begin{array}{l}100 \text { point visual analogue } \\
\text { scale (VAS) }\end{array}$ & $\begin{array}{l}\text { "How do you feel?" } \\
\text { "Would you return?" } \\
100 \text { point VAS scale }\end{array}$ & $\begin{array}{l}\text { Increased satisfaction with } \\
\text { respect, general treatment } \\
\text { and staff attitude related to } \\
\text { perceived level of initial } \\
\text { information. } p<0.05\end{array}$ \\
\hline Booth et $a l^{31} 1992$ UK & Waiting times & $\begin{array}{l}4 \text { point Likert scale and } \\
\text { open-ended questions }\end{array}$ & N/A & $\begin{array}{l}\text { Satisfaction levels with } \\
\text { components of waiting times. } \\
\text { "Ideal" and target times } \\
\text { derived. }\end{array}$ \\
\hline $\begin{array}{l}\text { Hansagi et al }{ }^{6} 1992 \\
\text { Sweden }\end{array}$ & $\begin{array}{l}\text { Multiple patient and service } \\
\text { factors, and triage category }\end{array}$ & $\begin{array}{l}\text { Likert scale and } \\
\text { open-ended questions }\end{array}$ & $\begin{array}{l}\text { "Satisfaction with medical } \\
\text { treatment" } \\
\text { "Satisfaction with general } \\
\text { care" } \\
\text { Weighted } 4 \text { point scale }\end{array}$ & $\begin{array}{l}\text { Triage category and age related } \\
\text { to global satisfaction. } \mathrm{p}<0.001\end{array}$ \\
\hline $\begin{array}{l}\text { Lewis et al } \\
1992 \text { Canada }\end{array}$ & $\begin{array}{l}\text { Triage category, nursing care, } \\
\text { physician care, environment, } \\
\text { auxiliary staff, waiting times } \\
\text { and information }\end{array}$ & $\begin{array}{l}3 \text { point Likert scale and } \\
\text { open-ended questions }\end{array}$ & $\begin{array}{l}\text { "Overall satisfaction with } \\
\text { ED visit" } \\
\text { Weighted } 3 \text { point scale }\end{array}$ & $\begin{array}{l}\text { Separate factor satisfaction } \\
\text { levels given. Poor correlation } \\
\text { between global satisfaction } \\
\text { derived from specific satisfaction } \\
\text { ratings and global satisfaction } \\
\text { on direct questioning. Only } \\
\text { triage category reported as } \\
\text { strongly correlated }\end{array}$ \\
\hline $\begin{array}{l}\text { Maitra et al } \\
1992 \text { UK }\end{array}$ & $\begin{array}{l}\text { Waiting times, receptionist } \\
\text { helpful, explanations of } \\
\text { management, information on } \\
\text { delays, interruptions, treatment } \\
\text { discussion with doctor }\end{array}$ & $\begin{array}{l}\text { Modified Likert scale and } \\
\text { open-ended question }\end{array}$ & $\begin{array}{l}\text { "Satisfied" or "not satisfied" } \\
\text { with outcome of visit } \\
\text { Dichotomous response }\end{array}$ & $\begin{array}{l}\text { Satisfaction correlates with wait } \\
\text { to see doctor }(p<0.003) \text {, } \\
\text { doctor's explanation of } \\
\text { management }(p<0.002) \text {, total } \\
\text { time in ED }(p<0.01)\end{array}$ \\
\hline $\begin{array}{l}\text { Bursch et al }{ }^{13} \\
1993 \text { USA }\end{array}$ & Multiple service factors & $\begin{array}{l}\text { Likert scale and } \\
\text { open-ended questions }\end{array}$ & $\begin{array}{l}\text { "Overall, how satisfied } \\
\text { with ED care?" } \\
\text { Unspecified scale }\end{array}$ & $\begin{array}{l}14 \text { service factors correlated } \\
\text { with global satisfaction. Top five } \\
\text { were: perceived waiting time; } \\
\text { caring nurses; ED staff } \\
\text { organisation; caring doctor; } \\
\text { information given. ( } r=0.63 \text { to } \\
0.68 \text { ) }\end{array}$ \\
\hline $\begin{array}{l}\text { Britten ef } a l^{14} \\
1994 \text { UK }\end{array}$ & $\begin{array}{l}\text { None specified to patients. } \\
\text { Twelve main themes identified } \\
\text { from interview transcripts }\end{array}$ & $\begin{array}{l}\text { Frequency and emphasis } \\
\text { in interview transcript }\end{array}$ & N/A & $\begin{array}{l}\text { Factors identified as important } \\
\text { are: information; waiting time; } \\
\text { quick pain relief; sensitivity to } \\
\text { personal circumstances; } \\
\text { excessive questions or } \\
\text { examination; a pleasant } \\
\text { environment }\end{array}$ \\
\hline $\begin{array}{l}\text { Thompson et al }{ }^{17} \\
1995 \text { USA }\end{array}$ & Perceived waiting time & Likert scale & $\begin{array}{l}\text { Describe your experience } \\
\text { in the ED. } \\
\text { Weighted } 4 \text { point scale. }\end{array}$ & $\begin{array}{l}\text { Perceived wait relative to } \\
\text { expected wait correlates with } \\
\text { overall satisfaction. } p<0.001\end{array}$ \\
\hline $\begin{array}{l}\text { Thompson et } a l^{8} \\
1996 \text { USA }\end{array}$ & $\begin{array}{l}\text { Perceived and actual waiting } \\
\text { times (to see doctor and for } \\
\text { entire visit). Explanation given } \\
\text { of delays, and procedures. } \\
\text { Staff attitudes }\end{array}$ & Open-ended questions & $\begin{array}{l}\text { Describe experience. } \\
\text { Recommendation } \\
\text { Weighted } 4 \text { and } 3 \text { point scales }\end{array}$ & $\begin{array}{l}\text { Information and perceived wait } \\
\text { (but not actual wait) correlate } \\
\text { with global satisfaction. } \\
p<0.001\end{array}$ \\
\hline $\begin{array}{l}\text { Hall et al } \\
1996 \text { USA }\end{array}$ & $\begin{array}{l}\text { Multiple demographic } \\
\text { and service factors }\end{array}$ & $\begin{array}{l}\text { Likert scale and } \\
\text { open-ended questions }\end{array}$ & $\begin{array}{l}\text { Recommendation } \\
\text { Weighted } 5 \text { point scale }\end{array}$ & $\begin{array}{l}\text { Nurse and doctor attitudes } \\
\text { (care, courtesy, concern), and } \\
\text { perceived wait intervals } \\
\text { correlate with global } \\
\text { satisfaction. No demographic } \\
\text { factor correlated (including age) }\end{array}$ \\
\hline $\begin{array}{l}\text { Rhee et al }{ }^{19} \\
1996 \text { USA }\end{array}$ & $\begin{array}{l}\text { Nurse and doctor technical } \\
\text { ability. Nurse and doctor } \\
\text { "bedside manner". } \\
\text { Receptionist service. } \\
\text { Perceived wait intervals }\end{array}$ & 5 point Likert scale & $\begin{array}{l}\text { Rate overall quality (weighted } \\
5 \text { point scale) } \\
\text { Recommendation (dichotomous) }\end{array}$ & $\begin{array}{l}\text { Patient perceptions of technical } \\
\text { quality of care }(p<0.001) \text { and } \\
\text { perceived waiting times } \\
(p<0.005) \text { correlate with global } \\
\text { satisfaction, and are more } \\
\text { important than bedside manner }\end{array}$ \\
\hline $\begin{array}{l}\text { Bruce et } a l^{32} \\
1998 \text { UK }\end{array}$ & $\begin{array}{l}30 \text { items on nursing care, } \\
\text { environment, ancillary } \\
\text { services and information }\end{array}$ & 3 point Likert scales & N/A & $\begin{array}{l}\text { Primary area of concern was } \\
\text { information about length of } \\
\text { waiting time }\end{array}$ \\
\hline $\begin{array}{l}\text { Yarnold et al' } 1998 \\
\text { (two part study) USA }\end{array}$ & $\begin{array}{l}\text { Perceived waiting times, } \\
\text { information and explanations, } \\
\text { staff attitudes }\end{array}$ & Likert scale & $\begin{array}{l}\text { "Overall satisfaction" } \\
\text { (symmetrical } 5 \text { point scale } \\
\text { and weighted } 4 \text { point scale) }\end{array}$ & $\begin{array}{l}\text { Overall satisfaction levels are } \\
\text { almost perfectly predictable } \\
\text { from ratings of perceived staff } \\
\text { attitudes }\end{array}$ \\
\hline $\begin{array}{l}\text { Boudreaux et } a l^{2} \\
2000 \text { USA }\end{array}$ & $\begin{array}{l}22 \text { items including registration, } \\
\text { nurse and doctor factors, } \\
\text { waiting times, discharge } \\
\text { instructions and estimated } \\
\text { length of stay }\end{array}$ & 5 point Likert scale & $\begin{array}{l}\text { Recommendation } \\
\text { Overall satisfaction }\end{array}$ & $\begin{array}{l}\text { Caring staff, perception of } \\
\text { safety, understanding discharge } \\
\text { instructions, nurse technical skills } \\
\text { and waiting time predict overall } \\
\text { satisfaction. ( } \mathrm{p}<0.05 \text { ) } \\
\text { Perceptions of care outweighed } \\
\text { demographics and visit } \\
\text { characteristics. Some differences } \\
\text { between predictors of overall } \\
\text { satisfaction and likelihood to } \\
\text { recommend }\end{array}$ \\
\hline
\end{tabular}


Table 1 Continued

\begin{tabular}{|c|c|c|c|c|}
\hline $\begin{array}{l}\text { Author, year, } \\
\text { and country }\end{array}$ & Factors assessed & $\begin{array}{l}\text { Method of assessing } \\
\text { factor satisfaction }\end{array}$ & $\begin{array}{l}\text { Method of assessing } \\
\text { global satisfaction }\end{array}$ & Main findings \\
\hline $\begin{array}{l}\text { Morgan et al } \\
2000 \text { UK }\end{array}$ & $\begin{array}{l}16 \text { varying paired } \\
\text { combinations of doctor's } \\
\text { manner, waiting time, service } \\
\text { accessibility, known doctor, } \\
\text { consultation type, doctor's shift. }\end{array}$ & $\begin{array}{l}\text { Conjoint analysis } \\
\text { (ranking of paired } \\
\text { preferences) }\end{array}$ & N/A & $\begin{array}{l}\text { Doctor's manner and waiting } \\
\text { times are the most important } \\
\text { factors. Patients will tolerate a } \\
\text { doctor who seems rushed if they } \\
\text { can be seen sooner }\end{array}$ \\
\hline $\begin{array}{l}\text { Sun et al } \\
2000 \text { USA }\end{array}$ & $\begin{array}{l}\text { Nine sociodemographic } \\
\text { variables, } 15 \text { comorbid } \\
\text { conditions, } 18 \text { process of } \\
\text { care measures. Triage score, } \\
\text { five service factors (courtesy, } \\
\text { completeness of care, } \\
\text { explanation, waiting time, } \\
\text { discharge instructions). } \\
19 \text { specified problems }\end{array}$ & 5 point Likert scale & $\begin{array}{l}\text { "Overall satisfaction" } \\
\text { (5 point Likert scale) } \\
\text { Willingness to return } \\
\text { (dichotomous response) }\end{array}$ & $\begin{array}{l}\text { Significant process of care } \\
\text { measures: triage status, number } \\
\text { of treatments. Significant } \\
\text { problems: no help when } \\
\text { needed; poor explanation of } \\
\text { problem cause and test results; } \\
\text { not informed about waiting time, } \\
\text { when to resume normal } \\
\text { activities, or when to reattend. } \\
\text { Significant patient factors: age } \\
\text { and race. Willingness to return } \\
\text { is strongly predicted by } \\
\text { satisfaction }\end{array}$ \\
\hline
\end{tabular}

\section{Patient factors that influence satisfaction}

Most studies collected data on some "background variables", such as age, sex, social status, ethnicity, and severity of illness. Age and race influenced satisfaction in some studies, ${ }^{56}$ but not all. ${ }^{7}$ Triage category was strongly correlated with satisfaction, ${ }^{568}$ although this could be viewed as another indicator of the waiting time.

Inclusion and exclusion criteria varied enormously between studies, and in some were unspecified. The "point of view paradox" dictates that as the severity of illness increases so patient expectations regarding non-clinical service factors decrease, ${ }^{9}$ so it is important to be aware of the population in which satisfaction is being measured.

Apart from Morgan et al's survey of Sheffield residents, ${ }^{10}$ multicentre studies by $\mathrm{Hall}^{7}$ and Sun, ${ }^{5}$ and Yarnold's comparison of an academic and community ED, ${ }^{11}$ most papers reported single centre studies. Table 2 shows the different survey methods, populations, and response rates. A few papers sampled the population in the form of a "census" - that is, they attempted to enlist every patient within the study population over the study period. Others used population sampling, either random, systematic, or by quota.

\section{Service factors that influence satisfaction}

Three broad headings cover the most commonly identified areas of importance. These are "interpersonal skills/perceived staff attitudes", ${ }^{10-13}$ "provision of information/explanation", $7^{73-18}$ and "aspects related to waiting times", particularly the perceived waiting time in relation to the patient's expectation. $^{7^{810} 12-141_{17-19}}$ The relative ranking of specific service factors in relation to global satisfaction remains unresolved.

\section{Intervention studies}

In total, seven controlled trials that studied satisfaction as a primary outcome measure were found, with two of these from the UK. Three assessed whether the provision of general information to patients on their arrival influenced overall satisfaction. ${ }^{20-22}$ Two of these related to written information, and one to an informational video. All three demonstrated improved satisfaction, as well as an improvement in the perception of other service factors, in the informed groups.

Two studies report improved patient satisfaction as a result of staff training. In one paper all ED staff underwent "customer service training", 23 while in the other doctors attended a communication skills workshop. ${ }^{24}$
The two UK papers focus on nurse triage, ${ }^{25}$ and an emergency nurse practitioner (ENP) service. ${ }^{26}$ Nurse triage had little effect on patient satisfaction, but a comparison between traditional ED and ENP care showed that ENP care led to improved satisfaction with some communication related service factors.

\section{DISCUSSION}

Many problems are inherent in the analysis of satisfaction in ED patients. Firstly, "satisfaction" is not easy to define, secondly, methods of quantifying and qualifying satisfaction are still emerging in emergency medicine, and thirdly, emergency physicians care for the largest and most diverse patient population.

\section{Quantifying "satisfaction"}

Studies aiming to correlate specific factors with "overall satisfaction" have chosen various tools with which to measure global and factor satisfaction. Techniques range from using simple questions with dichotomous answers, to non-directive interviewing techniques where "main themes" are identified. Direct questions using the word "satisfaction" have been used, or overall satisfaction is extrapolated from indirect questions such as "willingness to recommend" or "willingness to return". ${ }^{512}$ Combined factor satisfaction scores have also been used to predict overall satisfaction, ${ }^{15}$ although this approach has been questioned. ${ }^{8}$

Questionnaire validity is difficult to assess, as there is no "gold standard" for patient satisfaction. However, in some studies patient views have been "validated" against independent measures of doctors' interpersonal skills, communication styles, and technical proficiency. ${ }^{27}$

\section{Response rates}

Adequate survey response rates are a challenge to achieve, and vital for results to be meaningful. Response rates will be increased by "on the spot" surveys in the ED, although late night attendees have often been excluded by studies using convenience sampling. If surveys are conducted after the patient has left the ED, bias can be introduced by the delay, and responses tend to be more positive if the acute problem has resolved. ${ }^{28}$ Few studies to date have been longitudinal, assessing changes in attitude over time, ${ }^{15}$ although a small number make more than one approach to the respondent. ${ }^{5}$

Many ED patients are not competent to respond. Some surveys therefore include "accompanying person" respondents or, when the study population includes children, 
parent/guardian respondents. ${ }^{11} 13$ 16-19 Reported satisfaction levels in these situations are likely to be influenced by the factors most affecting the proxy respondent, for example, waiting times, facilities, communication, and access to the patient.

\section{Future directions}

The complexities of the relation between separate care factors and global satisfaction mean that local intervention studies will be unlikely to show striking improvements in overall satisfaction. Nevertheless, the existing literature does indicate which areas to concentrate on, and which approaches to use, in future research studies.

To assess the impact of specific interventions, and changes over time, a baseline must first be established. Methodologies for assessing patient satisfaction, both with individual service factors and the overall emergency department experience, are now becoming more thoroughly developed and refined. The most commonly used tool is a Likert scale, which offers a range of choices from strongly positive to strongly negative. Because patient responses are biased towards positive choices many researchers have used "asymmetrical" or "weighted" scales to overcome this. ${ }^{27}$ The number of points on the scales varies within and between papers, but it has been shown that scales with more than five responses do not carry significant advantages. ${ }^{27}$ Visual analogue scales are also popular, and give comparable results to Likert scales. ${ }^{27}$ Some authors have recently proposed other methods for satisfaction assessment. ${ }^{528}$

Focus groups may be used to identify key issues of patient concern. Data collected from such groups have been compared with government assumptions of what patients want, ${ }^{14}$ and used to validate questionnaire design. ${ }^{29}$ A review of complaints (and compliments) will also provide qualitative information that may be very useful at a local level.

Previous research indicates that three interventions worthy of further study are:

(1) Improving interpersonal, attitudinal and communication skills in ED staff. There is evidence that a short training course may be highly effective in this regard..$^{23}$

(2) Provision of more information and explanation.

(3) Reduction of the perceived waiting time.

Table 2 Methodology of factor and global satisfaction assessment studies

\begin{tabular}{|c|c|c|c|c|c|c|c|}
\hline $\begin{array}{l}\text { Author and } \\
\text { date }\end{array}$ & Survey format & Delivery & Timing & Respondent & $\begin{array}{l}\text { Survey } \\
\text { population }\end{array}$ & Sample & $\begin{array}{l}\text { Response } \\
\text { rate }(\%)\end{array}$ \\
\hline $\begin{array}{l}\text { Bjorvel and } \\
\text { Steig }^{15} 1991\end{array}$ & Questionnaire & Self completed & $\begin{array}{l}\text { On arrival } \\
\text { and before } \\
\text { discharge }\end{array}$ & Adult patients & $\begin{array}{l}\text { Not admitted, } \\
\text { classed by } \\
\text { selected problems }\end{array}$ & $\begin{array}{l}187 \text { patients. } \\
\text { Convenience }\end{array}$ & 77 \\
\hline $\begin{array}{l}\text { Booth et al }{ }^{31} \\
1992\end{array}$ & Questionnaire & Self completed & $\begin{array}{l}\text { During ED } \\
\text { visit }\end{array}$ & Not known & $\begin{array}{l}\text { Not admitted. Non- } \\
\text { ambulance patients }\end{array}$ & $\begin{array}{l}342 \text { patients. } \\
\text { Consecutive }\end{array}$ & $\begin{array}{l}45 \text { (some } \\
\text { incomplete) }\end{array}$ \\
\hline $\begin{array}{l}\text { Hansagi et } a l^{6} \\
1992\end{array}$ & Questionnaire & Postal & $\begin{array}{l}\text { Few days } \\
\text { after } \\
\text { discharge }\end{array}$ & Not known & $\begin{array}{l}\text { Not admitted, } \\
\text { or discharged within } \\
\text { four weeks }\end{array}$ & 567 patients & 75 \\
\hline $\begin{array}{l}\text { Lewis et } a l^{8} \\
1992\end{array}$ & $\begin{array}{l}\text { Two part } \\
\text { questionnaire }\end{array}$ & Self completed & $\begin{array}{l}\text { During ED } \\
\text { visit }\end{array}$ & Not known & All patients & $\begin{array}{l}152 \text { patients. } \\
\text { Systematic sample }\end{array}$ & Unknown \\
\hline $\begin{array}{l}\text { Maitra et al } \\
1992\end{array}$ & Questionnaire & Self completed & $\begin{array}{l}\text { In ED after } \\
\text { treatment }\end{array}$ & $\begin{array}{l}\text { Patient or } \\
\text { accompanying person }\end{array}$ & All ED patients & $\begin{array}{l}433 \text { patients. } \\
\text { Systematic sample }\end{array}$ & 51 \\
\hline $\begin{array}{l}\text { Bursch et al }{ }^{3} \\
1993\end{array}$ & Questionnaire & Telephone & $\begin{array}{l}\text { Within one } \\
\text { week of } \\
\text { discharge from } \\
\text { ward or ED }\end{array}$ & $\begin{array}{l}\text { Patient or parent/ } \\
\text { guardian }\end{array}$ & All patients & $\begin{array}{l}258 \text { patients. } \\
\text { Census }\end{array}$ & 59 \\
\hline $\begin{array}{l}\text { Britten et al }{ }^{14} \\
1994\end{array}$ & $\begin{array}{l}\text { Semi-structured } \\
\text { interview }\end{array}$ & $\begin{array}{l}\text { Trained } \\
\text { interviewer }\end{array}$ & $\begin{array}{l}\text { One or two days } \\
\text { after admission }\end{array}$ & Adult patients & $\begin{array}{l}\text { Adult patients, } \\
\text { admitted via } \\
\text { the ED }\end{array}$ & $\begin{array}{l}83 \text { patients. } \\
\text { Selected ward } \\
\text { inpatients }\end{array}$ & Unknown \\
\hline $\begin{array}{l}\text { Thompson } \\
\text { et } a l^{17} 1995\end{array}$ & Questionnaire & Telephone & $\begin{array}{l}\text { Two to four } \\
\text { weeks after } \\
\text { ED visit }\end{array}$ & $\begin{array}{l}\text { Adult patient or } \\
\text { parent/guardian }\end{array}$ & $\begin{array}{l}\text { All non- admitted } \\
\text { patients }\end{array}$ & $\begin{array}{l}1574 \text { patients. } \\
\text { Random sample }\end{array}$ & 43 \\
\hline $\begin{array}{l}\text { Thompson } \\
\text { et }\left.a\right|^{18} 1996\end{array}$ & Questionnaire & Telephone & $\begin{array}{l}\text { Two to four } \\
\text { weeks after } \\
\text { ED visit }\end{array}$ & $\begin{array}{l}\text { Adult patient or } \\
\text { parent/guardian. }\end{array}$ & $\begin{array}{l}\text { All non- admitted } \\
\text { patients with } \\
\text { recorded waiting } \\
\text { times }\end{array}$ & $\begin{array}{l}1631 \text { patients. } \\
\text { Random sample }\end{array}$ & 45 \\
\hline $\begin{array}{l}\text { Hall et al } \\
1996\end{array}$ & Questionnaire & Postal & $\begin{array}{l}\text { Three to four } \\
\text { days after } \\
\text { ED visit }\end{array}$ & Not specified & $\begin{array}{l}\text { Non-admitted } \\
\text { patients from } \\
187 \text { emergency } \\
\text { departments }\end{array}$ & $\begin{array}{l}9106 \text { patients. } \\
\text { Consecutive } \\
\text { sample }\end{array}$ & 25 \\
\hline $\begin{array}{l}\text { Rhee et al } \\
1996\end{array}$ & Questionnaire & Telephone & $\begin{array}{l}\text { Within } 60 \text { days } \\
\text { of } E D \text { visit }\end{array}$ & $\begin{array}{l}\text { Patients, parents/ } \\
\text { guardians or } \\
\text { accompanying person }\end{array}$ & All patients & $\begin{array}{l}618 \text { patients. } \\
\text { Random sample }\end{array}$ & 46 \\
\hline $\begin{array}{l}\text { Yarnold et al }{ }^{11} \\
1998 \text { (1) }\end{array}$ & Questionnaire & Postal & $\begin{array}{l}\text { One week } \\
\text { after ED visit }\end{array}$ & $\begin{array}{l}\text { Adult patient or } \\
\text { parent/guardian }\end{array}$ & $\begin{array}{l}\text { Non-admitted } \\
\text { patients from an } \\
\text { academic hospital }\end{array}$ & $\begin{array}{l}2277 \text { patients. } \\
\text { Consecutive sample }\end{array}$ & 17 \\
\hline $\begin{array}{l}\text { Yarnold et } a l^{\prime \prime} \\
1998(2)\end{array}$ & Questionnaire & Telephone & $\begin{array}{l}\text { Two to four } \\
\text { weeks after } \\
\text { visit }\end{array}$ & $\begin{array}{l}\text { Adult patient or } \\
\text { parent/guardian }\end{array}$ & $\begin{array}{l}\text { All non-admitted } \\
\text { patients from a } \\
\text { community hospital }\end{array}$ & $\begin{array}{l}\text { 1,287 patients. } \\
\text { Random sample }\end{array}$ & 53 \\
\hline $\begin{array}{l}\text { Boudreaux } \\
\text { et } a l^{\prime 2} 2000\end{array}$ & Questionnaire & Telephone & $\begin{array}{l}10 \text { days after } \\
\text { ED visit }\end{array}$ & Not known & Not known & 437 patients & 39 \\
\hline $\begin{array}{l}\text { Morgan et al } \\
2000\end{array}$ & $\begin{array}{l}\text { Focus group and } \\
\text { questionnaire }\end{array}$ & Postal & $\begin{array}{l}\text { Not related } \\
\text { to ED visits }\end{array}$ & $\begin{array}{l}\text { Adult Sheffield } \\
\text { residents }\end{array}$ & $\begin{array}{l}10800 \text { adult } \\
\text { responders to a } \\
\text { previous study }\end{array}$ & $\begin{array}{l}271 \text { respondents. } \\
\text { Random sample }\end{array}$ & 65 \\
\hline $\begin{array}{l}\text { Sun et } a l^{5} \\
2000\end{array}$ & $\begin{array}{l}\text { Medical notes } \\
\text { review } \\
\text { Questionnaires }\end{array}$ & $\begin{array}{l}\text { Self completed } \\
\text { questionnaire. } \\
\text { Telephone } \\
\text { interview }\end{array}$ & $\begin{array}{l}\text { In ED } 10 \text { days } \\
\text { after ED visit }\end{array}$ & Adult patients & $\begin{array}{l}\text { Adult patients } \\
\text { with selected, } \\
\text { high prevalence } \\
\text { problems from } \\
\text { five urban EDs. }\end{array}$ & $\begin{array}{l}2333 \text { patients. } \\
\text { Mixed convenience } \\
\text { and consecutive } \\
\text { samples. }\end{array}$ & 67 \\
\hline
\end{tabular}


The last is currently receiving considerable government attention in the $\mathrm{UK}^{30}$ with the anticipation that waiting times will fall and, presumably, patient satisfaction will improve. Future research could usefully study the effect of this and similar interventions in the ED, as well as clarifying the relative importance of the main service factors identified.

The preferred methodological approach to future intervention studies will depend upon local circumstances and the factor(s) under study. Over the past 10 years the design and interpretation of satisfaction studies has become increasingly sophisticated. Interest in qualitative, rather than quantitative, research methods is growing, and some recent studies have combined the two approaches in an attempt to develop more reliable and valid tools for measuring satisfaction. ${ }^{10} 29$ Multi-centre studies are generally preferable, because of their inmproved external validity, but very few have been reported to date. For some factors (such as patient information) a randomised design is feasible, but for other interventions (such as reductions in the perceived waiting time) alternative or novel approaches may be required.

\section{CONCLUSIONS}

To a great extent, patients must trust their clinicians to continuously review and improve their clinical and technical skills. The emphasis now placed on evidence based practice recognises this responsibility. However, in the quest to improve the science of medicine, medicine as an art may be suffering. The balance will be somewhat restored if we succeed in identifying, and responding to, wider patient needs. The study of patient satisfaction is a step in this direction.

Research to date has identified which broad aspects of the service our patients care most about. There are many potential interventions that could be tailored to local needs, and the papers already published can usefully inform future strategies for assessing and improving patient satisfaction in emergency medicine. We will never please "all of the people all of the time", but within our own departments we can now start investigating measures that will please more of our patients most of the time.

\section{Authors' affiliations \\ C Taylor, J R Benger, Emergency Department, Royal United Hospital, Bath, UK}

\section{REFERENCES}

1 Department of Health. The NHS plan: a plan for investment, a plan for reform. London: HMSO, 2000.

2 Anonymous. Involving patients and the public in healthcare: a discussion document. London: Department of Health, 2001.

3 Thomas EJ, Burstin HR, O'Neil AC, et al. Patient non-compliance with medical advice after the emergency department visit. Ann Emerg Med 1996;27:49-55.
4 Murray MJ, Le Blanc $\mathrm{CH}$. Clinic follow-up from the emergency department: Do patients show up? Ann Emerg Med 1996;27:56-8.

5 Sun BC, Adams J, Orav EJ, et al. Determinants of patient satisfaction and willingness to return with emergency care. Ann Emerg Med 2000;35:426-34.

6 Hansagi H, Carlsson B, Brismar B. The urgency of care need and patient satisfaction at a hospital emergency department. Health Care Manage Rev 1992;17:71-5

7 Hall MF, Press I. Keys to patient satisfaction in the emergency department: results of a multiple facility study. Hosp Health Serv Admin 1996;41:515-32.

8 Lewis KE, Woodside RE. Patient satisfaction with care in the emergency department. J Adv Nurs 1992;17:959-64.

9 Schwab RA. Emergency department customer satisfaction: the point of view paradox. Ann Emerg Med 2000;35:499-501.

10 Morgan A, Shackley P, Pickin M, et al. Quantifying patient preferences for out of hours primary care. J Health Serv Res Policy 2000:5:214-18.

11 Yarnold PR, Michelson EA, Thompson DA, et al. Predicting patien satisfaction: a study of two emergency departments. J Behav Med 1998;21:545-63.

12 Boudreaux ED, Ary RD, Mandry CV, et al. Determinants of patient satisfaction in a large municipal ED: the role of demographic variables, visit characteristics, and patient perceptions. Am J Emerg Med 2000; 18:394-400.

13 Bursch B, Beezy J, Shaw R. Emergency department satisfaction: what matters most? Ann Emerg Med 1993;22:586-91.

14 Britten N, Shaw A. Patients' experiences of emergency admission: how relevant is the British government's Patients Charter? J Adv Nurs 1994; 19:1212-20.

15 Bjorvell H, Steig J. Patients' perceptions of the healthcare received in an emergency department. Ann Emerg Med 1991;20:734-8.

16 Maitra A, Chikhani C. Patient satisfaction in an urban accident and emergency department. Br J Clin Pract 1992;46:182-4.

17 Thompson DA, Yarnold PR. Relating patient satisfaction to waiting time perceptions and expectations: the disconfirmation paradigm. Acad Emerg Med 1995; 2:1057-62.

18 Thompson DA, Yarnold PR, Williams DR, et al. Effects of actual waiting time, perceived waiting time, information delivery and expressive quality on patient satisfaction in the emergency department. Ann Emerg Med 1996;28:657-65.

19 Rhee, Bird J. Perceptions and satisfaction with emergency department care. J Emerg Med 1996;14:679-83.

20 Kologlu M, Agalar F, Cakmakci M. Emergency department information: does it affect patients' perception and satisfaction about the care given in an emergency department? Eur J Emerg Med 1999;6:245-8.

21 Krishell S, Baraff $\amalg$. Effect of emergency department information on patient satisfaction. Ann Emerg Med 1993;22:568-72.

22 Corbett SW, White PD, Wittlake WA. Benefits of informational videotape for emergency department patients. Am J Emerg Med 2000;18:67-71.

23 Mayer TA, Cates RI, Mastorovich MJ, et al. Emergency department patient satisfaction: Customer service training improves patient satisfaction and ratings of physician and nurse skill. Journal of Healthcare Management 1998;43:427-42

24 Lau FL. Can communication skills workshops for emergency department doctors improve patient satisfaction? Emerg Med J 2000;17:251-3.

25 George S, Read S, Westlake L, et al. Evaluation of nurse triage in a British accident and emergency department. BMJ 1992;304:876-8.

26 Byrne G, Richardson M, Brunsdon J, et al. Patient satisfaction with emergency nurse practitioners in A\&E. J Clin Nurs 2000;9:83-93.

27 Fitzpatrick R. Surveys of patient satisfaction: I-Important general considerations. BMJ 1991;302:887-9.

28 Trout A, Magnusson AR, Hedges JR. Patient satisfaction. Investigations in the emergency department: What does the literature say. Acad Emerg Med 2000;7:695-709.

29 McKinley RK, Manku-Scott T, Hastings AM, et al. Reliability and validity of a new measure of patient satisfaction with out of hours primary care in the UK: development of a patient questionnaire. BMJ 1997;314:193-8.

30 Department of Health. Reforming emergency care. London: HMSO, 2001.

31 Booth AJ, Harrison CJ, Gardener GJ, et al. Waiting times and patient satisfaction in the accident and emergency department. Archives of Emergency Medicine 1992;9:162-8.

32 Bruce TA, Bowman JM, Brown ST. Factors that influence patient satisfaction in the emergency department. J Nurs Care Qual 1998;13:31-7. 